\title{
Efek Metode STEAM pada Kreatifitas Anak Usia 5-6 Tahun
}

\author{
Siti Wahyuningsih", Adriani Rahma Pudyaningtyas², Ruli Hafidah ${ }^{3}$, Muhammad Munif \\ Syamsuddin ${ }^{4}$, Upik Elok Endang Rasmani ${ }^{5}$, Novita Eka Nurjanah ${ }^{6}$ \\ Pendidikan Guru Pendidikan Anak Usia Dini, Universitas Sebelas Maret \\ DOI: $\underline{10.31004 / \text { obsesi.v4i1.305 }}$
}

\begin{abstract}
Abstrak
Penelitian eksperimen ini bertujuan untuk menguji efek metode STEAM terhadap kreatifitas anak usia 5-6 tahun. Desain eksperimen menggunakan pretest dan post test dengan jumlah responden 25 anak. Hasil penelitian menunjukkan ada perbedaan kreativitas pada anak sebelum anak mendapatkan perlakuan dan sesudah anak mendapatkan perlakuan penerapan Metode STEAM. Metode STEAM dalam penerapannya menggunakan loosepart yang dapat meningkatkan kreatifitas anak. Kreativitas yang tinggi ditandai dengan Keterampilan berpikir lancar, Keterampilan berpikir fleksibel, Keterampilan berpikir orisinal dan Keterampilan berpikir merinci. Penerapan Metode STEAM dalam pelaksanaan pembelajaran dapat meningkatkan Kreativitas anak ditandai dengan anak mampu memecahkan masalah dan mampu membuat hubungan dengan lingkungan sekitar.
\end{abstract}

Kata kunci : metode steam, kreatifitas

\begin{abstract}
Abstact
This experimental study was aimed to test the effect of the STEAM method on the creativity children aged 5-6 years. Pretest and post test design was given to 25 children. The results showed there were differences in creativity in children before children received treatment and after children received treatment using the STEAM Method. STEAM method in its application uses loosepart which can increase children's creativity. High creativity is characterized by fluent thinking skills, flexible thinking skills, original thinking skills and detailed thinking skills. Application of STEAM Method in the implementation of learning can improve children's creativity marked by children able to solve problems and be able to make relationships with the surrounding environment.
\end{abstract}

Kata kunci : steam, creativity

Copyright (c) 2019 Siti Wahyuningsih, Adriani Rahma Pudyaningtyas, Ruli Hafidah, Muhammad Munif Syamsuddin, Upik Elok Endang Rasmani, Novita Eka Nurjanah

$\triangle$ Corresponding author :

Email Address : siti_w@staff.uns.ac.id (Slamet Riyadi Street No. 449, Pajang, Surakarta)

Received 16 October 2019, Accepted 27 November 2019, Published 28 November 2019

\section{PENDAHULUAN}

The Partnership for 21st century mengidentifikasi empat "Learning and Innovation skills", yang merupakan 4 hal paling pokok harus dimiliki, yaitu : creativity, critical thinking, communication, collaboration (Bishop \& Ph, 2017) . Keterampilan abad 21 sering disebut 4Cs, dalam bahasa Indonesia bisa diingat dengan singkatan $4 \mathrm{~K}$, yaitu kreativitas, kritis, komunikasi, kerjasama. Hal ini senada dengan teori Bloom bahwa kreativitas merupakan 
kemampuan yang paling tinggi dalam aspek perkembangan kognitif. Oleh karena itu, kreativitas penting diberikan pada Pendidikan Anak Usia Dini.

Pembelajaran pada anak usia dini untuk menstimulasi kreativitas dilakukan melalui berbagai program yang bervariasi. Pembelajaran yang dipersiapkan untuk menyongsong anak-anak untuk menghadapi abad 21 adalah pembelajaran berbasis Science, Technology, Engineering, Art, and Mathematics (STEAM). (Sciences) Sains seringkali merupakan mata pelajaran yang dibiarkan sampai hari akhir seandainya ada sedikit waktu yang tersisa, atau bahkan diabaikan oleh guru sama sekali. Namun, bagi anak-anak kecil, sering kali merupakan pokok bahasan yang paling membuat mereka penasaran, bersemangat, dan haus belajar (Krogh, S.L \& Slentz, 2008).

Menurut definisi, sains merujuk pada pengetahuan yang diperoleh secara sistematis melalui observasi, studi, dan eksperimen. Ketika diterapkan pada dunia alami, itu mencakup fisika, kimia, dan biologi serta turunan dan cabang mereka seperti astronomi, geologi, oseanografi, ekologi, botani, dan zoologi. Karena isi dari ilmu-ilmu ini adalah fisik, dapat didekati, dan terjalin dengan kehidupan anak-anak, sains tidak hanya menarik bagi mereka tetapi juga bagian yang sesuai dari kurikulum mereka. Kegiatan yang harus dilakukan guru dalam pembelajaran bidang sains untuk anak usia dini adalah: 1) rencanakan pengalaman sains dalam kaitannya dengan perkembangan fisik, sosial dan moral, emosional, dan kognitif anak-anak, 2) mengembangkan kurikulum sains yang mencerminkan kebutuhan masing-masing anak, dan 3) mulailah merencanakan unit studi sains yang mengintegrasikan bidang studi lainnya.

Teknologi itu istilah lain dari alat. Orang dewasa berpikir teknologi itu berupa barang elektronik atau peralatan digital seperti kamera, komputer atau mesin-mesin canggih di pabrik. Padahal krayon, pensil, penggaris, dan gunting juga alat. Peralatan apapun yang digunakan anak untuk bermain adalah teknologi, dari mulai teknologi sederhana sampai pada teknologi modern, dari mesin-mesin sederhana yang dapat ditemui anak dalam kehidupan sehari-hari. Perlu dipastikan bahwa teknologi tersebut sesuai usia anak dan dapat digunakan sesuai kemauan anak serta memberikan kesempatan untuk memecahkan masalah.

Menurut Jackman (2009), Technology di era revolusi 4.0 ini kita tidak bisa terlepas dari perkembangan teknologi yang begitu pesat. Hal ini karena teknologi tidak akan hilang dan kita berada di tengah-tengah pergeseran kuantum sosiokultural utama. teknologi ini merevolusi dunia tempat anak-anak kita akan tinggal. Jadi tugas kita adalah menyeimbangkan pengembangan keterampilan yang tepat dengan teknologi dengan prinsip-prinsip inti dan pengalaman yang diperlukan untuk membesarkan anak-anak yang sehat (Alam \& Perry, 2002). Oleh karena itu, teknologi ini penting untuk dikenalkan sejak usia dini.

Engineering dapat diartikan sebagai sebuah rekayasa terhadap teknologi. Engineering dimulai dengan mengidentifikasi masalah, kemudian mencoba memecahkan masalah itu. Sebagai contoh, anak-anak mengalami proses ketika mereka mencoba mencari tahu bagaimana membuat fondasi yang kuat agar bangunan balok mereka dapat lebih tinggi (Siantajani, 2018).

Seni ekspresif meliputi menggambar, melukis, patung, arsitektur, musik, sastra, drama, dan tarian. Seni menambah kekayaan dalam kehidupan, mengangkat pikiran dan perasaan kita melampaui peristiwa biasa dalam kehidupan kita sehari-hari. Dalam dunia anak usia dini, seni ekspresif adalah semua ini dan lebih banyak lagi. Seni menstimulasi perkembangan kognitif, sosial, emosional, dan fisik pada anak usia dini.

Anak-anak kecil berpartisipasi dalam musik dengan bernyanyi, mendengarkan, bergerak, mengarang, dan memainkan bahkan membuat sendiri instrumen mereka. Seni visual anak-anak antara lain menggambar, melukis segala jenis, berbagai jenis patung, dan bekerja dengan tanah liat atau bahan serupa. Kemampuan anak-anak dalam pengalaman 
DOI: $10.31004 /$ obsesi.v4i1.305

yang berhubungan dengan seni dipengaruhi oleh tingkat perkembangan mereka, dan sebaliknya, kurikulum seni berkontribusi pada semua bidang perkembangan anak-anak.

Bidang matematika mencakup berbagai subbidang, keterampilan, dan sistem, yang banyak di antaranya sesuai untuk dipelajari dalam beberapa bentuk oleh anak kecil. Di antara topik yang lebih umum diajarkan adalah klasifikasi; seriasi; perhitungan; pengukuran; geometri; grafik; dan aritmatika (Krogh, S.L \& Slentz, 2008). Aktivitas yang diterapkan oleh guru dalam dalam bidang matematika untuk anak usia dini, yaitu: 1) rencanakan kegiatan matematika untuk menstimulasi perkembangan fisik, sosial, dan kognitif anak-anak, 2) rencanakan kegiatan matematika dengan mempertimbangkan kebutuhan masing-masing anak, dan 3) memasukkan kegiatan matematika ke dalam semua area kurikulum.

Bahasa juga berperan dalam matematika, ketika anak menggunakan kata-kata perbandingan seperti: lebih besar, lebih tebal, dan lebih kecil. Kemampuan berpikir matematika tingkat tinggi muncul ketika anak dibantu untuk memahami bahwa perbandingan adalah relatif, tergantung dari apa yang dibandingkan pada saat itu.

Konsep matematika lebih baik dipahami ketika matematika menjadi bagian dari kegiatan sehari-hari. Bidang kurikulum lainnya dapat memasukkan matematika dengan mudah dan sukses. Selain itu, menurut NAEYC dan NCTM (2002):

"Anak-anak kecil tidak memandang dunia mereka seolah-olah terbagi menjadi lubanglubang kecil yang terpisah seperti "matematika" atau "literasi". Juga, praktik yang efektif tidak membatasi matematika untuk satu periode atau waktu tertentu. sebaliknya, guru anak usia dini membantu anak-anak mengembangkan pengetahuan matematika sepanjang hari dan melintasi kurikulum. lingkungan kelas diatur sehingga anak-anak dapat menyelidiki matematika melalui banyak jenis pengalaman langsung (Michel \& Wortham, 2007)".

Pembelajaran berbasis Science, Technology, Engineering, Art, and Mathematics (STEAM) diajarkan secara terintegrasi di PAUD. Loose parts (lepasan) adalah unsur yang penting dari pembelajaran berbasis STEAM. Loose parts merupakan barang-barang yang terbuka, yang mudah ditemukan di lingkungan sehari-hari. Alam kita penuh dengan loose parts, seperti ranting, biji pinus, kerang, batu, daun, bunga dan benda-benda alam lainnya. Orangtua dan guru dapat mengumpulkan loose parts dari manapun, tanpa mengeluarkan biaya.

Loose parts ini bukan hanya mendukung perkembang anak, tetapi juga membantu anak untuk menghubungkan dirinya dengan lingkungannya. Mainan dirancang dengan satu tujuan khusus, dan biasanya digunakan anak dengan satu atau dua cara saja. Anak yang membawa sekeranjang mobil-mobilan, biasanya akan menggunakan mobil-mobilan untuk dimainkan seperti menjalankan mobil. Namun ketika anak menggunakan benda-benda di alam, ia dapat menggunakannya untuk apapun sesuai dengan ide anak. Ini akan mengembangkan imajinasi, kreativitas, bahasa dan pengetahuan anak.

STEAM digunakan untuk fokus pada pemahaman tentang sifat terintegrasi dari disiplin sains, teknologi, teknik, seni, dan matematika serta pentingnya mereka dalam keberhasilan akademik jangka panjang anak-anak, kesejahteraan ekonomi (Quigley \& Herro, 2016), dan pengembangan masyarakat (Han, Rosli, Capraro, \& Capraro, 2016). Pendidikan STEM mencakup nilai dari prasekolah hingga tingkat pasca-doktoral dan pengaturan pembelajaran formal (misal ruang kelas) dan pendidikan informal (misal Program afterschool) (Gonzalez \& Kuenzi, 2012). Sebagai gambaran, pendidikan STEM telah diakui di AS sebagai reformasi pendidikan yang penting dan digambarkan sebagai pendekatan instruksional untuk mempersiapkan anak-anak menghadapi ekonomi global abad ini (Yakman \& Lee, 2012)

Sasaran penelitian ini adalah anak usia 5-6 tahun di TK Aisyiyah Sumber III dan TK Al Huda Surakarta. Tujuan penelitian ini adalah mengimplementasikan pembelajaran pada PAUD berbasis Science, Technology, Engineering, Art, And Mathematics (STEAM) untuk mengembangkan kreativitas anak serta menerapkan model pembelajaran aktif dan kreatif, dimana anak berperan aktif dalam menggali informasi mengenai hal-hal baru dalam diri anak melalui lingkungan sekitar. 


\section{METODOLOGI}

Variabel dalam penelitian ini adalah metode STEAM sebagai variable bebas $(X)$ dan kreatifitas sebagai variable terikat $(Y)$. Penyusunan instrumen ini mengacu pada teori kreativitas Torrance atau dikenal dengan torrance test of creativi thingking yang terdiri dari Keterampilan berpikir lancar (fluency), Keterampilan berpikir fleksibel (flexibility), Keterampilan berpikir orisinal (originality), dan Keterampilan berpikir merinci/elaborasi (elaboration).

Partisipan dalam penelitian berjumlah 25 anak kelompok B berusia 5-6 tahun diambil dari dua sekolah (TK Aisyiah Sumber III dan TK Alhuda) Surakarta. Pengambilan sampel menggunakan purpossive sampling atas pertimbangan karakteristik anaknya sama, TK tersebut pernah mengikuti sosialisasi STEAM dan pernah menerapkan STEAM pada pembelajaran.

Peneliti melakukan observasi ke dua TK terlebih dahulu untuk melihat proses pembelajaran yang dilakukan dan melihat kemampuan anak khususnya kreativitas. Peneliti melakukan koordinasi dengan pihak TK untuk melaksanakan penelitian berbasis Science, Technology, Engineering, Art, and Mathematics (STEAM) yang diterapkan di TK Aisyiyah Sumber III dan TK Al Huda. Langkah selanjutnya yang dilakukan oleh tim peneliti adalah melakukan penyusunan instrumen kreativitas pada anak kelompok B (usia 5-6 tahun). penyusunan instrumen ini mengacu pada teori kreativitas Torrance atau dikenal dengan torrance test of creativi thingking yang terdiri dari Keterampilan berpikir lancar (fluency), Keterampilan berpikir fleksibel (flexibility), Keterampilan berpikir orisinal (originality), dan Keterampilan berpikir merinci/elaborasi (elaboration). Setelah instrumen sudah siap peneliti melakukan pretest untuk mengukur kreativitas anak di dua TK tersebut.

Instrumen yang sudah siap peneliti gunakan untuk pretest di TK TK Aisyiyah Sumber III dan TK Al Huda Surakarta untuk mengukur kreativitas anak kelompok B (usia 5-6 tahun). Setelah pretest dilakukan, peneliti menyusun perangkat pembelajaran dan media pembelajaran yang akan digunakan.

Sebelum diberikan kepada sampel, instrumen ini di uji coba terlebih dahulu. Soal di ujicoba instrumen kemudian diuji validitas dan diukur reliabilitasnya untuk melihat kebenarannya. Validitas butir instrumen dilakukan dengan menggunakan Pearson Product Moment. Pengujian reliabilitas instrumen ini merupakan pengujian lanjutan setelah butir soal instrumen dinyatakan valid. Pengujian reliabilitas menggunakan rumus koefisien Alpha Cronbach. Untuk kebutuhan analsis yang tepat maka diperlukan pengkajian persyaratan analisis yaitu uji normalitas dan homogenitas data.

Pengujian hipotesis menggunakan statistic parametrik dan uji-t untuk menguji perbedaan sebelum dan setelah dilakukan perlakuan. Data akhir diolah dengan menggunakan SPSS.

Tabel 1. Uji Prasyarat

\begin{tabular}{lc}
\hline Uji prasyarat & Signifikansi $(\rho)$ \\
\hline Normalitas & \\
Pretest & 0.281 \\
Post test & 0.388 \\
Homogenitas & 0.630 \\
\hline \multicolumn{2}{r}{ Ket $: \rho \geq 0.05$} \\
& Analisis data \\
\hline Waktu & Signifikansi $(\rho)$ \\
\hline Pretest---Post & 0.000 \\
test & \\
\hline
\end{tabular}

Ket : $\rho \leq 0,05$ 
DOI: 10.31004/obsesi.v4i1.305

\section{HASIL DAN PEMBAHASAN}

Dampak dari penerapan model pembelajaran STEAM dalam kegiatan pembelajaran anak usia 5 hingga 6 tahun salah satunya berupa pengembangan kreativitas siswa, atau sebagai sarana untuk meningkatkan keterampilan pemecahan masalah dalam kegiatan sehari-hari (Perignat \& Katz-Buonincontro, 2019). Beberapa alasan yang bisa menjelaskan bahwa model pembelajaran STEAM dapat meningkatkan kreativitas anak adalah pertama anak diajarkan untuk belajar berproses berupa kegiatan mengamati, bermain, mengenali pola dan berlatih keterampilan berfikir kreatif serta keterampilan kolaborasi dan komunikasi antar anak yang lainnya dalam menyelesaikan suatu tugas yang diberikan oleh guru maupun fasilitator (Guyotte, Sochacka, Costantino, Walther, \& Kellam, 2014)Kedua pembelajaran yang digunakan berbasis teknologi ilmiah dan kemampuan untuk memecahkan masalah di dunia nyata (Kofac, 2017). Ketiga dalam pembelajaran STEAM anak dilatih untuk berani menyampaikan ekspresi diri baik berupa kritikan maupun pendapat. Dari hal tersebut meningkatkan keterampilan komunikasi verbal dan nonverbal anak serta adanya keterbukaan terhadap persepsi orang lain maupun pemahaman terhadap hal-hal baru dalam diri anak melalui refleksi dari pengalaman dan emosi diri mereka sendiri (Seidel, S., Tishman, S., Winner, E., Hetland, L., \& Palmer, 2009)

Keempat mengembangkan potensi anak untuk membuat koneksi antara bahan pembelajaran, desain pembelajaran serta lingkungan disekitarnya(Sochacka, N. W., Guyotte, K. W., \& Walther, 2016). Kelima anak-anak yang belajar di dalam kelas dengan menggunakan metode STEAM tidak mengetahui bahwa mereka akan menemukan berbagai informasi yang tumpang tindih sehingga dengan adanya hal ini akan menuntut anak untuk berfikir kreatif dan kritis terhadap hal-hal baru yang di terima oleh anak. Selain itu mereka juga didorong untuk memecahkan masalah bersama guru dan teman sebayanya (Michaud, 2014).

Pengembangan keterampilan berfikir kreatif harus dimula sejak anak duduk dibangku taman kanak-kanak, dimana pada tahap ini anak perlu didorong untuk membayangkan, menciptakan, mengenali berbagai pengetahuan dan praktik. Penting bagi orang tua maupun fasilitator dalam membangun sudut pandang perseptual, konseptual dan analitis anak sejak usia dini, karena pada tahap ini mereka memasuki akar kreativitas diri yang akan mempengaruhi masa depan mereka (Yalcin, 2015).

Bentuk kegiatan nyata pengembangan kreatifitas anak adalah ketika anak diberikan bahan-bahan pembelajaran bertemakan apotik, anak-anak sudah dapat berfikir kreatif untuk membuat obat-obatan dari bahan yang telah di sediakan dan saling berbagi informasi mengenai cara pembuatan obat dan mengemas obat yang benar sesuai dengan kreatifitas masing-masing anak. Selain itu ketika anak-anak diberikan berbagai bentuk ukuran balok, anak dapat menyalurkan kreativitasnya untuk mengubah balok menjadi bangunan seperti rumah sakit, rumah, garasi, bahkan bangunan gedung bertingkat.

STEAM merupakan akronim dari Science, Technology, Engineering, Arts, and Mathematics. Model pembelajaran STEAM memiliki dampak terhadap anak usia dini alah satunya yaitu meningkatkan minat siswa dan pemahaman dalam teknologi dan kemampuan untuk memecahkan masalah di dunia nyata (Thuneberg, Salmi, \& Bogner, 2018). Seperti yang dijelaskan oleh Kofac (2017) bahwa STEAM memuat pembelajaran berbasis teknologi ilmiah dan kemampuan dalam memecahkan masalah di dunia nyata.

Selain itu dengan model pembelajaran STEAM mendorong anak untuk mengembangkan rasa ingin tahu, keterbukaan pengalaman (Perignat \& Katz-Buonincontro, 2019) dan mengajukkan pertanyaan sehingga anak membangun pengetahuan disekitarnya dengan mengeksplorasi, mengamati, menemukan, dan menyelidiki sesuatu yang ada disekitarnya (Munawar, 2019). Fokus STEAM adalah pada menciptakan yaitu produk akhir dan proses pembuatan. Proses pembuatan lebih penting dibanding produk akhir karena di dalam prosesnya terdapat aspek eksplorasi, pemikiran kreatif, desain teknik, ekspresi kreatif, evaluasi, dan desain ulang (Perignat \& Katz-Buonincontro, 2019). Dalam proses tersebut, model STEAM dapat mengajarkan anak untuk berproses melalui kegiatan 
mengamati, bermain, mengenali pola, dan berlatih keterampilan berpikir kreatif serta keterampilan kerjasama dan komunikasi antar anak dalam menyelesaikan suatu tugas atau project yang diberikan oleh guru (Guyotte, K. W., Sochacka, N. W., Costantino, T. E., Walther, J., \& Kellam, 2014) Selain itu dalam berproses anak dituntut untuk berpikir kreatif dan kritis pada hal-hal baru yang didapat oleh anak. Anak juga terdorong untuk memecahkan masalah bersama guru dan teman sebayanya (Michaud, 2014).

Kreativitas dalam kelas contohnya pengembangkan lingkungan yang mendukung dimana siswa merasa terdorong untuk berpikir, bereksplorasi, bermain, mengamati, merefleksikan, dan mengajukan pertanyaan yang tidak biasa. Kreativitas belajar melalui contoh dan praktek langsung oleh karena itu guru bisa menjadi model perilaku yang kreatif dan mampu membangun kreatif pada diri siswa (Perignat \& Katz-Buonincontro, 2019). Dengan lingkungan yang mendukung, anak mampu untuk membuat koneksi antara bahan pembelajaran, lingkungan sekitarnya, dan desain pembelajaran (Seidel, S., Tishman, S., Winner, E., Hetland, L., \& Palmer, 2009).

\section{SIMPULAN}

Efek metode STEAM membawa anak pada peningkatan kreativitas dalam cara berpikir. Mereka menjadi lebih mampu dalam memecahkan persoalan-persoalan yang dihadapi menjadi lebih efektif. Catatan dalam penelitian ini jika anak yang sehat diberikan metode yang tepat maka anak-anak akan meningkat di dalam kualitas menyelesaikan tugas memecahkan problem yang dihadapi.

\section{UCAPAN TERIMAKASIH}

Dengan selesainya penelitian ini penulis mengucapkan terima kasih kepada seluruh pihak yang membantu khususnya rekan-rekan peneliti PG-PAUD UNS yang telah berjuang untuk menyelesaikan penelitian serta TK Aisyiyah Sumber III dan TK Al-Huda Kerten sehingga penelitian ini dapat terlaksana dengan baik, lancer dan sukses.

\section{DAFTAR PUSTAKA}

Alam, I., \& Perry, C. (2002). A customer-oriented new service development process. Journal of Services Marketing. https:/ / doi.org/10.1108/08876040210443391

Bishop, J., \& Ph, D. (2017). 21st Century Skills ( P21 ).

Gonzalez, H. B., \& Kuenzi, J. (2012). What Is STEM Education and Why Is It Important? Congressional Research Service.

Guyotte, K. W., Sochacka, N. W., Costantino, T. E., Walther, J., \& Kellam, N. N. (2014). STEAM as social practice: Cultivating creativity in transdisciplinary spaces. Art Education, 67(6), 12-19.

Guyotte, K. W., Sochacka, N. W., Costantino, T. E., Walther, J., \& Kellam, N. N. (2014). Steam as Social Practice: Cultivating Creativity in Transdisciplinary Spaces. Art Education. https:// doi.org/10.1080/00043125.2014.11519293

Han, S., Rosli, R., Capraro, M. M., \& Capraro, R. M. (2016). The effect of Science, technology, engineering and mathematics (STEM) project based learning (PBL) on students' Achievement in four mathematics topics. Journal of Turkish Science Education. https:// doi.org/10.12973/tused.10168a

Jackman, H. L. (2009). Early Education Curriculum A Child's Connection to the World Fourth Edition. USA: WADSWORTH CENGAGE Learning.

Kofac. (2017). Concept and definition of STEAM. Seoul: The Korea Foundation for the Advancement of Science and Creativity - KOFAC.

Krogh, S.L \& Slentz, K. L. (2008). The Early Childhood Curriculum. New Jersey: Lawrence Erlbaum Associates, Inc. 
DOI: 10.31004/obsesi.v4i1.305

Michaud, M. R. (2014). STEAM : Adding Art to STEM education. District Administration, 50(1), 64 .

Michel, A., \& Wortham, S. (2007). Listening beyond the self: How organizations create direct involvement. Learning Inquiry, 1(2), 89-97. https:// doi.org/10.1007/s11519-007-0016$\mathrm{y}$

Munawar, D. (2019). Implementation of STEAM (Science Technology Engineering Art Mathematics)-based early childhood education learning in Semarang City. Jurnal Ceria, 2(5), 2714-4107.

NAEYC and NCTM. (2002). https://www.naeyc.org/sites/default/files/globally shared/downloads/PDFs/resources/position-statements/psmath.pdf. Diakses pada 14 November 2019, Pukul 18.00.

Perignat, E., \& Katz-Buonincontro, J. (2019). STEAM in practice and research: An integrative literature review. Thinking Skills and Creativity. https://doi.org/10.1016/j.tsc.2018.10.002

Quigley, C. F., \& Herro, D. (2016). "Finding the Joy in the Unknown": Implementation of STEAM Teaching Practices in Middle School Science and Math Classrooms. Journal of Science Education and Technology. https://doi.org/10.1007/s10956-016-9602-z

Seidel, S., Tishman, S., Winner, E., Hetland, L., \& Palmer, P. (2009). The qualities of quality: Understanding excellence in arts education. Cambridge: MA: Project Zero, Harvard Graduate School of Education. Retrieved from http://www.wallacefoundation.org/knowledge-center/Documents/UnderstandingExcellence-in-Arts-Education.pdf.

Siantajani, Y. (2018). Playing with loose parts. Modul (tidak diterbitkan).

Sochacka, N. W., Guyotte, K. W., \& Walther, J. (2016). Learning together: A collaborative autoethnographic exploration of STEAM (STEM + the arts) education. Journal of Engineering Education, 105(1), 15-42. https:// doi.org/doi:10.1002/jee.20112

Thuneberg, H. M., Salmi, H. S., \& Bogner, F. X. (2018). How creativity, autonomy and visual reasoning contribute to cognitive learning in a STEAM hands-on inquiry-based math module. Thinking Skills and Creativity. https:/ / doi.org/10.1016/j.tsc.2018.07.003

Yakman, G., \& Lee, H. (2012). Exploring the Exemplary STEAM Education in the U.S. as a Practical Educational Framework for Korea. Journal of The Korean Association For Science Education. https://doi.org/10.14697/jkase.2012.32.6.1072

Yalcin, M. (2015). Progressive Development of Creative Design Skills from Kindergarden Education. FormAkademisk - Forskningstidsskrift for Design Og Designdidaktikk. https://doi.org/10.7577/formakademisk.1403 